Available online on 15.12.2020 at http://jddtonline.info
OC 2011-18, publisher and licensee JDDT, This is an Open Access article which permits
unrestricted non-commercial use(CC By-NC), provided the original work is properly cited

Open $\odot$ Access

Research Article

\title{
Synthesized Silver Nanoparticle Loaded Gel of Curcuma Caesia for Effective Treatment of Acne
}

\author{
Nivedita Rai*, Tarkeshwar P. Shukla, Kavita R. Loksh, Sarita Karole \\ Oriental College of Pharmacy, Raisen Road, Patel Nagar, Bhopal, Madhya Pradesh 462022, India
}

\begin{abstract}
Objective: The objective of our research is to prepare silver nanoparticles from the rhizome extract of Curcuma caesia and develop topical herbal gel formulation for the effective treatment of acne.

Methods: In this present study, silver nanoparticles were synthesized using hydroalcoholic extract of Curcuma caesia rhizome. Silver nanoparticles loaded gels were evaluated for $\mathrm{pH}$, viscosity, spreadability, in vitro release, estimation of total flavonoids and alkaloid content and antibacterial (propioni bacterium acne) studies.

Results: The synthesized silver nanoparticles were stable, spherical shape with average particle size of $220.5 \mathrm{~nm}$. The results obtained in the developed formulation showed no lumps, had uniform color dispersion and were free from any fiber and particle. It was also ob served to have easy washablity, good spreadability, pH was found to be $6.58 \pm 0.02$ and $7.02 \pm 0.01$ similar to pH of the skin. The antibacterial study of the developed formulation showed inhibitory activity against Propioni bacterium acne. Synthesized silver nanoparticle loaded gel displayed drug release of optimized formulation F3 follows the Higuchi kinetic model, and the mechanism is found to be non Fickian/anomalous according to Korsmeyer-Peppas. Silver nanoparticles effectively inhibited the growth of both microorganism indicating good antibacterial properties.
\end{abstract}

Conclusion: Synthesis of silver nanoparticles using Curcuma caesia is a new, green method and not reported yet, as per literature survey done for this project. Successful synthesis and evaluation of silver nanoparticles was proved by the in-vitro study.

Keywords: Curcuma caesia, Silver nanoparticles, Propioni bacterium acne, Acne, Flavonoids content, Alkaloid content, Antibacterial.

Article Info: Received 04 Oct 2020; $\quad$ Review Completed 19 Nov 2020; $\quad$ Accepted 27 Nov 2020; Available online 15 Dec 2020

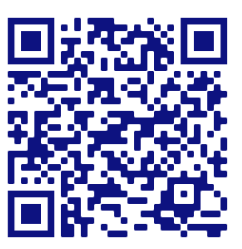

Cite this article as:

Rai N, Shukla TP, Loksh KR, Karole S, Synthesized Silver Nanoparticle Loaded Gel of Curcuma Caesia for Effective Treatment of Acnes, Journal of Drug Delivery and Therapeutics. 2020; 10(6-s):75-82 http://dx.doi.org/10.22270/jddt.v10i6-s.4453

*Address for Correspondence:

Nivedita Rai, Oriental College of Pharmacy, Raisen Road, Patel Nagar, Bhopal, Madhya Pradesh 462022, India

\section{INTRODUCTION}

Skin in the human being is the most susceptible part for entering various microorganisms into the body 1 . Acne vulgaris is one of the most prevalent skin diseases which affect the young adults in the age group between 11 and 30 years. Among these age group $50.9 \%$ of women and $42.5 \%$ of men are susceptible to this acne vulgaris 2, 3. Hormonal influences, altered keratinization, inflammation and immune changes are the multiple factors involved in the formation of acne 4,5 . Acne vulgaris is a common dermatological condition associated with depression, anxiety and other psychological sequences 3, 6,7. Microorganisms such as Propioni bacterium, Staphylococcus and Escherichia species are responsible for the development of acne ${ }^{8}$. Metallic silver in the form of silver nanoparticles (SNPs) has made a remarkable comeback as a potential antimicrobial agent. These nanoparticles are most promising as they show good antibacterial properties due to

ISSN: 2250-1177 their large surface area to volume ratio ${ }^{9}$. Medicinal plants play a major role in the discovery of new therapeutic agents for drug development 10. Curcuma caesia Roxb, a member of the family Zingiberaceae and commonly known as black turmeric, is a perennial, erect rhizomatous herb with bluishblack rhizome of high economical importance because of its medicinal values. It is native to North-East and Central India. Rhizomes of the plant are aromatic with intense camphoraceous odour.The rhizomes are reported to contain anti-inflammatory agents, and the paste of fresh rhizomes is used as a remedy for insect and snake bite by the Khamti tribe of Lohit district of eastern Arunachal Pradesh 11. Rhizomes of the plant are used for sprains and bruises and also employed in the preparation of cosmetics ${ }^{12}$. Taking into consideration of the cost and easy availability of this medicinal plant, our present study was designed to explore systematically and analyze the phytoconstituents, synthesis nanoparticle by using plant extract then formulate topical gel CODEN (USA): JDDTAO 
containing silver nanoparticle and evaluate for its physicochemical properties and antibacterial activity.

\section{MATERIALS AND METHODS}

\section{Plant materials}

The rhizomes of Curcuma caesia were collected from local area of Bhopal in the month of January, 2020.

\section{Chemicals}

Chemicals were obtained from Rankem Laboratory Chemicals Pvt. Ltd., Haryana, India, Himedia Laboratories Pvt. Ltd, Mumbai, India and Loba Chemie, Mumbai, India. All solvents used were of analytical grade.

\section{Defatting of plant material}

Rhizomes of Curcuma caesia were shade dried at room temperature. The shade dried plant material was coarsely powdered and subjected to extraction with petroleum ether by maceration. The extraction was continued till the defatting of the material had taken place.

\section{Extraction by maceration process}

Dried powdered rhizomes of Curcuma caesia has been extracted with hydroalcoholic solvent (ethanol: water: 80:20) using maceration process for $48 \mathrm{hrs}$, filtered and dried using vacuum evaporator at $40^{\circ} \mathrm{C}$.

\section{Determination of plant yield}

The percentage yield was obtained using this formula W2$\mathrm{W} 1 / \mathrm{W} 0 \times 100$. Where $\mathrm{W} 2$ is the weight of the extract and the container, W1 the weight of the container alone and W0 the weight of the initial dried sample.

\section{Phytochemical analysis}

Methanol extract was analyzed for its phytoconstituents such as saponins, anthraquinone glycosides, phyto steroids, tannins, flavonoids, carbohydrates, triterpenoids, polyphenol and alkaloids 13,14

\section{Determination of total flavonoid content}

The total flavonoid content of the rhizome extract was determined by aluminum chloride colorimetric assay. Briefly, $0.5 \mathrm{ml}$ aliquots of the extract and standard solution (0.01-1.0 $\mathrm{mg} / \mathrm{ml}$ ) of quercitin were added with $2 \mathrm{ml}$ of distilled water and subsequently with $0.15 \mathrm{ml}$ of sodium nitrite $5 \%$ NaNO2 $, \mathrm{w} / \mathrm{v})$ solution and mixed. After 6 minutes, $0.15 \mathrm{ml}$ of $(10 \%$ $\mathrm{AlCl} 3, \mathrm{w} / \mathrm{v}$ ) solution was added. The solutions were allowed to stand for further $6 \mathrm{~min}$ and after that $2 \mathrm{ml}$ of sodium hydroxide $(4 \% \mathrm{NaOH}, \mathrm{w} / \mathrm{v})$ solution was added to the mixture. The final volume was adjusted to $5 \mathrm{ml}$ with immediate addition of distilled water, mixed thoroughly and allowed to stand for another $15 \mathrm{~min}$. The absorbance of each mixture was determined at $510 \mathrm{~nm}$ against the same mixture but without seed extract as a blank. TFC was determined as mg quercitin equivalent per gram of sample with the help of calibration curve of quercitin. All determinations were performed in triplicate $(n=3){ }^{15}$.

\section{Determination of total alkaloid content}

Total alkaloid content was also quantified by spectrophotometric method. This method is based on the reaction between alkaloid and bromocresol green (BCG). The plant extract $(1 \mathrm{mg} / \mathrm{ml})$ was dissolved in $2 \mathrm{~N} \mathrm{HCl}$ and then filtered. The $\mathrm{pH}$ of phosphate buffer solution was adjusted to neutral with $0.1 \mathrm{~N} \mathrm{NaOH} .1 \mathrm{ml}$ of this solution was transferred to a separating funnel, and then $5 \mathrm{ml}$ of BCG solution along with $5 \mathrm{ml}$ of phosphate buffer were added. The mixture was shaken and the complex formed was extracted with chloroform by vigorous shaking. The extract was collected in a $10 \mathrm{ml}$ volumetric flask and diluted to volume with chloroform. The absorbance of the complex in chloroform was measured at $470 \mathrm{~nm}$. The whole experiment was conducted in three replicates.

\section{Preparation of atropine standard curve}

Accurately measured aliquots $(0.5,1,1.5,2$, and $2.5 \mathrm{ml})$ of atropine standard solution were taken and transfer each to different separating funnels. To each solution, $5 \mathrm{ml}$ of phosphate buffer ( $\mathrm{pH} \mathrm{4.7)}$ along with $5 \mathrm{ml}$ of BCG solution were added and shaken vigorously with $4 \mathrm{ml}$ of chloroform. The extracts were collected in $10 \mathrm{ml}$ volumetric flasks and then diluted to adjust volume up to the mark with chloroform. Now, the absorbance of the complex in chloroform was measured at $470 \mathrm{~nm}$ against the blank prepared as above but without atropine. Line of regression from atropine was used for estimation of unknown alkaloid content 16,17 .

\section{Biosynthesis of silver nanoparticles}

$\mathrm{AgNO}_{3}$ powder was dissolved in distilled water to prepare 10 $\mathrm{mM} \mathrm{AgNO}_{3}$ stock solution from which a series of $1 \mathrm{mM}, 2 \mathrm{mM}$ and $3 \mathrm{Mm} \mathrm{AgNO}{ }_{3}$ solutions were prepared. The $\mathrm{AgNO}_{3}$ solutions were mixed with the hydroalcoholic extract of rhizomes of Curcuma caesia at a ratio of $1: 1$, and 1:2 (v/v) to a volume of $50 \mathrm{~mL}$ in a flask. The flask was wrapped with an aluminum foil and was then heated in a water bath at $60^{\circ} \mathrm{C}$ for 5 hrs. Furthermore, the mixture was stored in the refrigerator for the further use.

Table 1: Different formulation of silver nanoparticles

\begin{tabular}{|c|c|c|c|}
\hline Formulation Code & Extract (mg) & AgN03 (mM) & Ratio \\
\hline F1 & 500 & 1 & $1: 1$ \\
\hline F2 & 500 & 2 & $1: 1$ \\
\hline F3 & 500 & 1 & $1: 2$ \\
\hline F4 & 500 & 2 & $1: 2$ \\
\hline F5 & 500 & 3 & $1: 2$ \\
\hline F6 & 500 & 3 & \\
\hline
\end{tabular}




\section{Determination of entrapment efficiency and drug content}

The entrapment efficiency of the drug into the beads was determined after separation of the beads from the free drug remaining in solution. The entrapment efficiency (EE) was calculated using the equation:

\section{$\mathrm{EE}(\%)=$}

[(Total drug added - amount of free drug)/total drug added] x 100

The drug content in the beads was determined by crushing known amount of dry beads a mortar with a pestle before soaking in $100 \mathrm{ml}$ of phosphate buffer $(\mathrm{pH}$ of 7.4) with continuous stirring using overhead stirrer for 60 minutes. This provided complete swelling and bursting of the beads. The resultant dispersion was filtered through $0.45 \mu \mathrm{m}$ membrane filter and the concentration of drug in the solution was determined spectrophotometrically after appropriate dilution using phosphate buffer ( $\mathrm{pH}$ of 7.4)18.

The drug content was calculated as the percentage drug load was given by the formula:

$$
\% \text { Drug load }=(\text { WD } / \text { WB }) \times 100
$$

Where, WD is the amount of drug loaded in beads and WB is the weight of beads.

\section{Particle size determination}

Mean particle size and size distribution of silver nanoparticle loaded gel was determined by photon correlation spectroscopy using Nanophox at room temperature. Before measurement, batch was diluted. The SNPs solutions were homogeneous throughout with no sedimentation and were light orange in color. The width of the size distribution was indicated by the polydispersity index (PDI) using following formula-PDI $=(\mathrm{X} 90-\mathrm{X} 10) / \mathrm{X} 50$.

\section{Zeta potential determination}

The silver nanoparticle loaded gel were subjected to zeta potential analysis to determine the surface charge of the nanoparticles, so as to predict their aggregation behavior

Formulation development of silver nanoparticles gel of optimized formulations (F3)

Topical gel formulations of optimized formulations F3 were prepared by cold mechanical method with defined quantity of carbopol 940 and polyethylene glycol 600. The specified quantity (1 g) of polymers were weighed separately and sprinkled slowly on surface of purified water ${ }^{19}$. To this defined quality of double distilled water was added with vigorous stirring and left overnight for dissolving the polymer. To the polymer solution, drug silver nanoparticles were added to the gel with continuous stirring. Required quantity of methyl paraben was added and mixed well by using magnetic stirrer. After complete dispersion, the $\mathrm{pH}$ of the gel was adjusted to neutral $\mathrm{pH} 7$ by using triethanolamine. Distilled water was added and made up to $100 \mathrm{~g} \mathrm{20,21}$. The herbal formulation composition is shown in table 2 .

Table 2: Formulation of silver nanoparticles gel of optimized formulations (F3)

\begin{tabular}{|c|c|c|c|}
\hline Ingredients (mg) & SNG1 & SNG2 & SNG3 \\
\hline Curcuma caesia silver nanoparticles & 500 & 500 & 750 \\
\hline Carbopol 940 & 250 & 500 & 0.2 \\
\hline Polyethylene Glycol 600 & 0.2 & 0.2 & 0.08 \\
\hline Methyl Paraben & 0.08 & 0.08 & 1.0 \\
\hline Triethanolamine & 1.0 & 1.0 & $100 \mathrm{ml}$ \\
\hline Distilled Water & $100 \mathrm{ml}$ & $100 \mathrm{ml}$ & \\
\hline
\end{tabular}

\section{Physicochemical evaluation of formulations}

Physical evaluation: Physical parameters such as color, appearance and consistency were checked visually 22,23 .

pH: Aqueous solution (1\%) of the formulation was measured by using a calibrated digital $\mathrm{pH}$ meter at constant temperature 22,23 .

Viscosity: Brookfield Viscometer (Brookfield Engineering Laboratories, USA) with spindle \#C 50-1 was used to measure the viscosity of the formulated topical gel at a speed of $50 \mathrm{rpm}$ in room temperature. Measurement of viscosity was done in triplicate 22,23 .

Spreadability: Glass slides with standard dimension (length of $6.0 \mathrm{~cm}$ ) were taken. Topical gel formulation was placed on the one side of the glass slide and sandwiched with the help of another slide. Remove the adhering gel on the outer surface of the glass slides by wiping. Slides are fixed in a stand that only upper slide to slip off freely without any disturbance by force of weight $(20 \mathrm{~g})$ tied to it. Time taken for the movement of upper slide to the distance of $6.0 \mathrm{~cm}$ was measured 22,23. Measurement of spreadability was done in triplicate and calculated by using the following formula:

Spreadability $=($ Weigh $\mathrm{x}$ Length $) /$ Time

Where, $\mathrm{S}=$ Spreadability $\mathrm{m}=$ Weight tied to the upper slide $(20$ g) $\mathrm{l}=$ Length of the glass $(6.0 \mathrm{~cm}) \mathrm{t}=$ Time taken in seconds

\section{In vitro drug release of formulated silver nanoparticle loaded gel}

In vitro drug release study was achieved with some modifications. Dialysis tubing (MWCO of $12000 \mathrm{Da}$ ) placed in the release medium under constant stirring using dissolution apparatus. The membrane was soaked in phosphate buffer solution for 24 hours and opened from both sides and then a quantity of $5 \mathrm{~g}$ of eight silver nanoparticle loaded gel formulations were individually packed into dialysis tube with the ends being tightly fastened. The membrane was fixed around the paddle of the USP dissolution test apparatus and submerged in the dissolution jar previously filled with $500 \mathrm{~mL}$. The medium was maintained at $37{ }^{\circ} \mathrm{C} \pm 0.5$ and stirred continuously at $50 \mathrm{rpm}$. Aliquots of $5 \mathrm{~mL}$ of the release medium were withdrawn at predetermined time 
intervals (10 min, 0.5, 1, 1.5, 2, 3, 4, 6, 8, 10, 12, 20 and $24 \mathrm{~h}$ ) and replaced by fresh phosphate buffer to provide sink condition. Each withdrawn sample was measured using UVvisible spectrophotometer at a $\lambda \lambda \max$ of $280 \mathrm{~nm}$. Absorbance was converted to drug concentration using a linear equation of calibration curve and then the cumulative percentage of drug released was calculated taking into consideration the dilution factor. All measurements were performed in triplicate $(n=3)$.

\section{Release kinetics study}

To study the release kinetics of drug from the silver nanoparticle loaded gel, the data obtained from the in vitro release study were analysed using various kinetic models to describe the mechanism of drug release from the hydrogels 24.

\section{Antibacterial activity}

\section{Preparation of inoculums}

For evaluation of antibacterial activity, $24 \mathrm{~h}$ fresh culture of bacteria was suspended in sterile water to obtain a uniform suspension of microorganism.

\section{Determination of zone of inhibition}

Antibacterial activity was checked by agar well diffusion method. In this method a previously liquefied medium was inoculated with $0.1 \mathrm{~mL}$ bacterial suspension having a uniform turbidity at temperature of $40^{\circ} \mathrm{C}$. In a sterile petri dish having an internal diameter of $8.5 \mathrm{~cm}$ was taken, $20 \mathrm{~mL}$ of culture medium was poured into it. Care was taken to form a uniform thickness of the medium in different plates. Wells were made aseptically with cork borer having $6 \mathrm{~mm}$ diameter after complete solidification of liquefied inoculated medium. In each of these plate extract, silver nanoparticle gel formulation were placed carefully. Plates were kept for pre diffusion for $30 \mathrm{~min}$ at room temperature; then the plates were incubated at $37^{\circ} \mathrm{C}$ for $24 \mathrm{~h}$ and the zones of inhibition were measured 23,25 .

\section{RESULTS AND DISCUSSION}

To obtain the percentage yield of extraction is very important phenomenon in phytochemical extraction to evaluate the standard extraction efficiency for a particular plant, different parts of same plant or different solvents used. The yield of extracts obtained from sample using pet ether and hydroalcoholic solvents are shown in the table. 3 .

Table 3: \% yield of rhizomes of Curcuma caesia

\begin{tabular}{|c|c|c|}
\hline S. No. & Solvents & \% Yield \\
\hline 1. & Pet ether & 2.347 \\
\hline 2. & Hydroalcoholic & 6.598 \\
\hline
\end{tabular}

Taken a small amount of the dried extracts and subjected to the phytochemical screening test by using Kokate methods to test for flavonoids, alkaloids, glycosides, tannins, saponins, phenol and steroids separately for extracts of all samples. The outcomes of the results are discussed in the table 4 . From the results obtained it is clear that the hydrolacoholic extract shows the occurrence of alkaloids, flavonoids, proteins, carbohydrates and saponins.

Table 4: Phytochemical screening of extract of rhizomes of Curcuma caesia

\begin{tabular}{|c|c|c|}
\hline S. N. & Constituents & $\begin{array}{c}\text { Hydroalcoholic } \\
\text { extract }\end{array}$ \\
\hline 1. & $\begin{array}{c}\text { Alkaloids } \\
\text { Mayer's Test } \\
\text { Wagner's Test } \\
\text { Dragendroff's Test } \\
\text { Hager's Test }\end{array}$ & $\begin{array}{l}\text {-ve } \\
\text { +ve } \\
\text {-ve } \\
\text { +ve }\end{array}$ \\
\hline 2. & $\begin{array}{c}\text { Glycosides } \\
\text { Modified Borntrager's Test } \\
\text { Legal's Test }\end{array}$ & $\begin{array}{l}\text {-ve } \\
\text {-ve }\end{array}$ \\
\hline 3. & $\begin{array}{l}\text { Flavonoids } \\
\text { Lead acetate } \\
\text { Alkaline test }\end{array}$ & $\begin{array}{l}\text { +ve } \\
+ \text { ve }\end{array}$ \\
\hline 4. & $\begin{array}{c}\text { Phenol } \\
\text { Ferric chloride test }\end{array}$ & -ve \\
\hline 5. & $\begin{array}{c}\text { Proteins } \\
\text { Xanthoproteic test }\end{array}$ & $+\mathrm{ve}$ \\
\hline 6. & $\begin{array}{l}\text { Carbohydrates } \\
\text { Molisch's Test } \\
\text { Benedict's Test } \\
\text { Fehling's Test }\end{array}$ & $\begin{array}{l}\text {-ve } \\
\text {-ve } \\
\text { +ve }\end{array}$ \\
\hline 7. & $\begin{array}{l}\text { Saponins } \\
\text { Froth Test } \\
\text { Foam Test }\end{array}$ & $\begin{array}{l}\text { +ve } \\
+ \text { ve }\end{array}$ \\
\hline 8. & $\begin{array}{c}\text { Diterpenes } \\
\text { Copper acetate test }\end{array}$ & -ve \\
\hline 9. & $\begin{array}{c}\text { Tannins } \\
\text { Gelatin Test }\end{array}$ & -ve \\
\hline
\end{tabular}

Total flavonoids content was calculated as quercetin equivalent $(\mathrm{mg} / 100 \mathrm{mg})$ using the equation based on the calibration curve: $\mathrm{Y}=0.032 \mathrm{X}+0.018, \mathrm{R}^{2}=0.998$, where $\mathrm{X}$ is the quercetin equivalent (QE) and $\mathrm{Y}$ is the absorbance. Total flavonoids content was found to be $0.967 \mathrm{mg} / 100 \mathrm{mg}$ of dried extract. Total alkaloid content was calculated as atropine equivalent $\mathrm{mg} / 100 \mathrm{mg}$ using the equation based on the calibration curve: $\mathrm{Y}=0.007 \mathrm{X}+0.024, \mathrm{R}^{2}=0.995$, where $\mathrm{X}$ is the Atropine equivalent (AE) and $\mathrm{Y}$ is the absorbance. Total flavonoids content was found to be $0.855 \mathrm{mg} / 100 \mathrm{mg}$ of dried extract. 
Table 5: Estimation of total flavonoids and alkaloid content

\begin{tabular}{|c|c|c|c|}
\hline S. No. & Extract & $\begin{array}{c}\text { Total flavonoids content } \\
\text { (mg/ 100 } \mathbf{~ m g ~ o f ~ d r i e d ~ e x t r a c t ) ~}\end{array}$ & $\begin{array}{c}\text { total alkaloid content } \\
\text { (mg/ 100 mg of dried extract) }\end{array}$ \\
\hline 1. & Hydroalcoholic & 0.967 & 0.855 \\
\hline
\end{tabular}

The percentage yield of prepared formulations was found in the range of $63.32 \pm 0.65$ to $73.32 \pm 0.41$ percentage, which was within the acceptable limits. The outcomes of the results are discussed in the table 6.

Table 6: Determination of \% yield of prepared formulations

\begin{tabular}{|c|c|}
\hline Formulation & \% Yield \\
\hline F1 & $69.45 \pm 0.25$ \\
\hline F2 & $65.58 \pm 0.32$ \\
\hline F3 & $73.32 \pm 0.41$ \\
\hline F4 & $63.32 \pm 0.65$ \\
\hline F5 & $65.52 \pm 0.23$ \\
\hline F6 & $68.85 \pm 0.56$ \\
\hline
\end{tabular}

Percentage entrapment efficiency (Flavonoid mg/100mg quercetin equivalent) was found in range of $0.616 \pm 0.007$ to $0.958 \pm 0.006$ percentage. The outcomes of the results are discussed in the table 7.

Table 7: Determination of entrapment efficiency of prepared formulations

\begin{tabular}{|c|c|}
\hline Formulation & $\begin{array}{c}\text { Percentage entrapment efficiency } \\
\text { (Flavonoid mg/100mg quercetin } \\
\text { equivalent) }\end{array}$ \\
\hline F1 & $0.821 \pm 0.005$ \\
\hline F2 & $0.769 \pm 0.004$ \\
\hline F3 & $0.958 \pm 0.006$ \\
\hline F4 & $0.652 \pm 0.007$ \\
\hline F5 & $0.723 \pm 0.005$ \\
\hline F6 & $0.616 \pm 0.007$ \\
\hline
\end{tabular}

The particle size determination is a very important criterion for the evaluation of nanoparticulate systems. Since it is difficult to distinguish between nanoparticles and micro particles, the particle size analysis gives the idea about the nanosizing of the silver nanoparticle loaded gel. The outcomes of the results of average particle size and zeta potential are discussed in the table 8 . Values of Zeta potential showed that prepared silver nanoparticle loaded gel have sufficient charge and mobility to inhibit aggregation of nanoparticles. Zeta potential was found to be negative for silver nanoparticle loaded gel. Since the Zeta potential of was found to be negative, it automatically reveals the stability of nanoparticles against aggregation potential. The repulsion of negatively charged particles leads to behave as separate entities in a nanoparticulate suspension 26.
Table 8: Characterization of formulation of silver nanoparticles for average particle size and zeta potential

\begin{tabular}{|c|c|c|}
\hline Formulation & $\begin{array}{c}\text { Average Particle size } \\
\text { (nm) }\end{array}$ & $\begin{array}{c}\text { Zeta Potential } \\
\text { (mV) }\end{array}$ \\
\hline F1 & 298.5 & -15.5 \\
\hline F2 & 265.5 & -14.6 \\
\hline F3 & 220.5 & -38.5 \\
\hline F4 & 248.8 & -25.6 \\
\hline F5 & 256.6 & -22.3 \\
\hline F6 & 289.9 & -25.4 \\
\hline
\end{tabular}

Visual inspection results indicate that prepared topical gel formulation has uniform color distribution and free from any lumps, fibers and foreign particles.

Bioavailability and therapeutic property of the topical formulation depends upon the spreadability. The spreadability is expressed of time in seconds based on the slip off from the gel by upper slide under certain load. Time taken for the separation of the two slides is less which indicates the topical formulation has better spreadability. The spreadability value was found to be $6.58 \pm 0.45$ (g.cm/sec) and $8.85 \pm 0.25$ (g.cm/ csec) for gel prepared by polyethylene glycol and Carbopol. The observed results were comparable with the earlier literature 20 .

Table 9: Results of spreadability of gel

\begin{tabular}{|c|c|}
\hline Formulation & Spreadability* $(\mathrm{gcm} / \mathbf{s e c})$ \\
\hline SNG1 & $8.85 \pm 0.25$ \\
\hline SNG2 & $7.65 \pm 0.36$ \\
\hline SNG3 & $6.58 \pm 0.45$ \\
\hline
\end{tabular}

*Average of three determinations $(\mathrm{n}=3 \pm \mathrm{SD})$

The viscosity was performed to assess the effect of the type and concentration of the gelling agent on the physical properties of the final silver nanoparticle loaded gel products and their viscosity ${ }^{28}$. Table 10 shows the viscosities of gel formulations at low and high shear rates. It can be seen in the figure that the effect of the types of gelling agents on the viscosity. Generally, the formulations of carbopol have higher viscosity than other formulations, because carbopol is a cross-linked polymer of acrylic acid with high molecular weight that has the ability to absorb and retain water upon neutralization, resulting in a viscous gel.

Table 10: Results of viscosity of gel

\begin{tabular}{|c|c|}
\hline Formulation & Viscosity* (cp) \\
\hline SNG1 & 2545 \\
\hline SNG2 & 2341 \\
\hline SNG3 & 2254 \\
\hline
\end{tabular}

*Average of three determinations $(\mathrm{n}=3 \pm \mathrm{SD})$ 
Flavonoids have one hydroxyl group that is substituted with aromatic ring. Flavonoids combine with metal ions and form chelate complex and can easily oxidized and donating electrons to scavenge free radicles [27. Higher flavonoid component is correlated with increased antioxidant activity 28. The outcomes of the results are discussed in the table 11.

Table 11: Results of flavonoid content in gel using $\mathrm{AlCl}_{3}$ method

\begin{tabular}{|c|c|}
\hline Formulation & $\begin{array}{c}\text { Flavonoid Content } \\
\text { (mg/100mg) }\end{array}$ \\
\hline SNG1 & $0.658 \pm 0.054$ \\
\hline SNG2 & $0.954 \pm 0.065$ \\
\hline SNG3 & $0.823 \pm 0.042$ \\
\hline
\end{tabular}

*Average of three determinations $(\mathrm{n}=3 \pm \mathrm{SD})$

$\mathrm{pH}$ was found in range of $6.58 \pm 0.02$ to $7.02 \pm 0.01$ for gel prepared by carbopol and polyethylene glycol as gel base which is near to the $\mathrm{pH}$ of the skin and hence is found to be compatible with skin. The outcomes of the results are discussed in the table 12.

Table 12: Results of $\mathrm{pH}$ of gel

\begin{tabular}{|c|c|}
\hline Formulation & $\mathbf{p H}$ \\
\hline SNG1 & $6.98 \pm 0.02$ \\
\hline SNG2 & $7.02 \pm 0.01$ \\
\hline SNG3 & $6.58 \pm 0.02$ \\
\hline \multicolumn{2}{|c|}{ *Average of three determinations (n=3 \pm SD) }
\end{tabular}

The formulations contain gelling agents to study the effect of the type and concentration of gelling agents on the release profile of the drug from the silver nanoparticle loaded gel. The results revealed that there is no considerable delay on drug release thereby as carbopol was used; about $90 \%$ of drug was released after 6 hours with more delay in release profile comparing with the other gel formulas.

Table 13: In vitro drug release study of prepared gel formulation

\begin{tabular}{|c|c|c|c|c|}
\hline \multirow{2}{*}{ S. No. } & Time (hr) & \multicolumn{3}{|c|}{ \% Cumulative Drug Release } \\
\cline { 2 - 5 } & & SNG1 & SNG2 & SNG3 \\
\hline 1 & 0.25 & 11.56 & 8.45 & 5.65 \\
\hline 2 & 0.5 & 23.32 & 15.65 & 11.25 \\
\hline 3 & 1 & 36.58 & 32.25 & 23.36 \\
\hline 4 & 1.5 & 45.85 & 43.32 & 31.47 \\
\hline 5 & 2 & 69.98 & 62.25 & 39.98 \\
\hline 6 & 2.5 & 95.56 & 75.65 & 48.85 \\
\hline 7 & 3 & 98.86 & 89.98 & 53.32 \\
\hline 8 & 4 & 99.12 & 99.45 & 69.98 \\
\hline
\end{tabular}

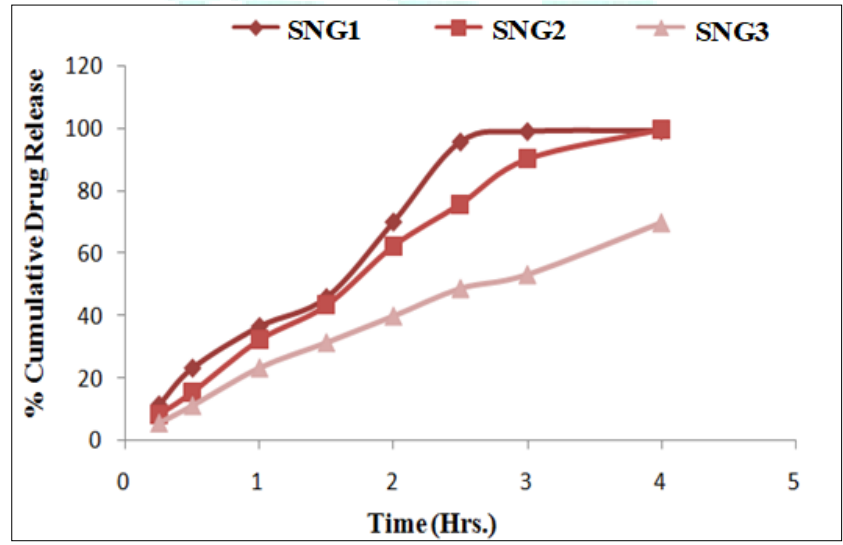

Figure 1: Graph of gel formulation SNG1, SNG2 and SNG3

Further optimized formulation SNG2 selected on the basis of physicochemical evaluation of formulations and in vitro studies further in vitro release kinetics studies was carried out. It can be observed in the figure that graphical representation of cumulative $\%$ of drug release against time represents that drug release from silver nanoparticle loaded gel is perfectly following release model as the drug release profile is very closest to trend line or regression line and the highest value of coefficient of correlation values $\left(R^{2}\right)$ was in the range of $0.817-0.973$. 
Table 14: In-vitro drug release data for gel SNG2

\begin{tabular}{|c|c|c|c|c|c|c|}
\hline $\begin{array}{c}\text { Time } \\
\text { (h) }\end{array}$ & $\begin{array}{c}\text { Square Root of } \\
\text { Time(h) }\end{array}$ & Log Time & $\begin{array}{c}\text { Cumulative*\% Drug } \\
\text { Release }\end{array}$ & $\begin{array}{c}\text { Log Cumulative } \\
\text { \% Drug Release }\end{array}$ & $\begin{array}{c}\text { Cumulative \%o } \\
\text { Drug Remaining }\end{array}$ & $\begin{array}{c}\text { Log Cumulative } \\
\text { \% Drug } \\
\text { Remaining }\end{array}$ \\
\hline 0.25 & 0.5 & -0.602 & 8.45 & 0.927 & 91.55 & 1.9617 \\
\hline 0.5 & 0.707 & -0.301 & 15.65 & 1.195 & 84.35 & 1.9261 \\
\hline 1 & 1 & 0 & 32.25 & 1.509 & 67.75 & 1.8309 \\
\hline 1.5 & 1.225 & 0.176 & 43.32 & 1.637 & 36.68 & 1.7534 \\
\hline 2 & 1.414 & 0.301 & 62.25 & 1.879 & 24.35 & 1.3865 \\
\hline 2.5 & 1.581 & 0.398 & 75.65 & 1.954 & 10.02 & 1.0009 \\
\hline 3 & 1.732 & 0.477 & 89.98 & 1.998 & 0.55 & -0.2596 \\
\hline 4 & 2 & 0.602 & 99.45 & & \\
\hline
\end{tabular}

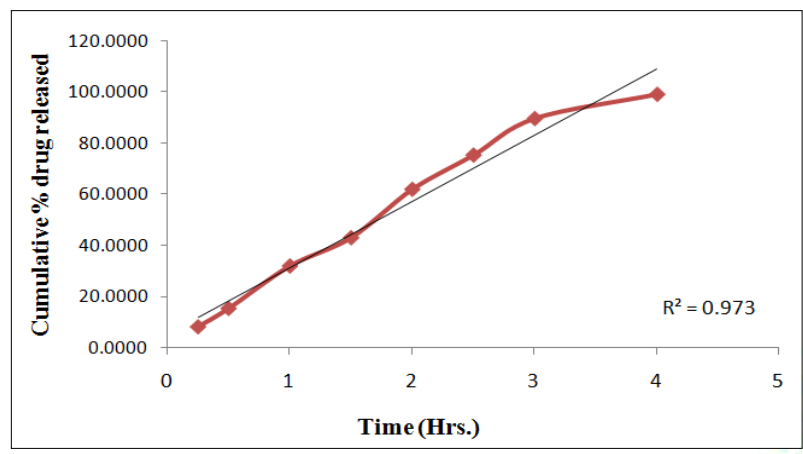

Figure 2: Graph of Zero order Release Kinetics of gel SNG2

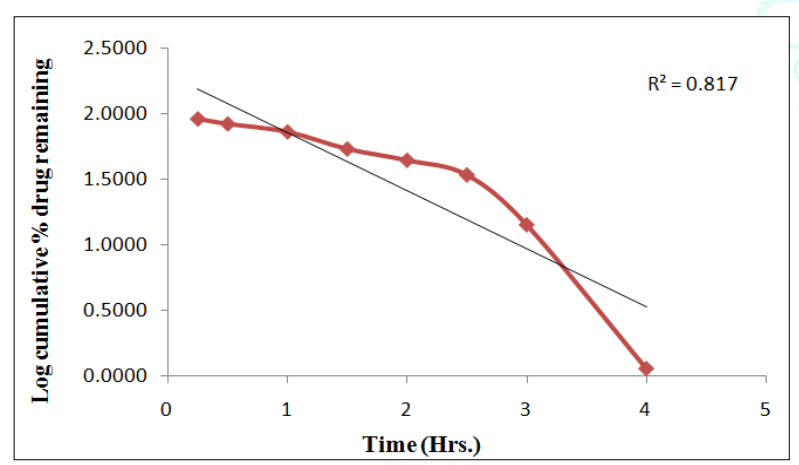

Figure 3: Graph of first order Release Kinetics of gel SNG2
The selection of an adequate model for fitting drug release data is important for determining the release characteristics using model-dependent approaches. When evaluating models with different parameters, because R2 increases with the number of included parameters, the adjusted coefficient of determination should be used. Taking into account the initial "burst release", the mathematical equations must be adjusted accordingly. Table 15 synthesizes the calculated values for the coefficient of determination corresponding to each mathematical model. As shown, the formulations follow zero-order and first-order kinetics.

Table 15: Release Kinetics Regression values of formulation SNG2

\begin{tabular}{|c|c|c|}
\hline Formulation code & Zero order & First order \\
\hline SNG2 & 0.973 & 0.817 \\
\hline
\end{tabular}

The antibacterial activity study results of the formulated silver nanoparticle loaded gel showed antibacterial activity against acne causing bacteria Propionibacterium acnes (P. acnes). The antibacterial study reveals that the silver nanoparticle loaded gel of Curcuma caesia showed higher activity than the extract against pathogen. The antibacterial activity of the study results are shown in table 16.

Table 16: Antimicrobial activity against selected microbes

\begin{tabular}{|c|c|c|c|c|c|}
\hline S. No. & Name of drug & Microbes & \multicolumn{3}{|c|}{ Zone of inhibition } \\
\cline { 4 - 6 } & & & $\mathbf{2 5} \mathbf{~ m g} / \mathbf{m l}$ & $\mathbf{5 0 ~} \mathbf{~ m g} / \mathbf{m l}$ & $\mathbf{1 0 0} \mathbf{~ m g} / \mathbf{m l}$ \\
\hline 1. & Extract & Propionibacterium acnes & $8 \pm 0.47$ & $12 \pm 0.74$ & $14 \pm 0.86$ \\
\cline { 4 - 6 } 2. & $\begin{array}{c}\text { Silver nanoparticles } \\
\text { gel (SNG2) }\end{array}$ & & $9 \pm 0.94$ & $13 \pm 0.5$ & $17 \pm 0.57$ \\
\hline
\end{tabular}

From the present study, it can be concluded that the preparation of silver nanoparticle loaded gel of Curcuma caesia proved to be a new and successful approach to obtain stable silver nanoparticle loaded gel. The optimized batch of silver nanoparticle loaded gel showed optimum particle size of nanoparticles. Zeta potential analysis result reveals the stability of optimized silver nanoparticle loaded gel formulation against aggregation. Thus, silver nanoparticle loaded gel proved the potential for topical delivery over the conventional formulations. 


\section{CONCLUSION}

The present study reveals a simple, rapid and economical method to synthesize silver nanoparticle loaded gel from Curcuma caesia. From the results obtained in this research, one can affirm that Curcuma caesia rhizome extract can play an important role in the stabilization of silver ions to silver nanoparticle. As a promising source of bioactive compounds, it can be an excellent source of useful drugs. The antibacterial activity is well demonstrated by agar well diffusion method. The synthesized silver nanoparticle using Curcuma caesia extract showed higher activity than the extract. Therefore, it was concluded that our formula could be very promising topical alternative for the treatment of bacterial infection. However, further preclinical, clinical and longterm stability studies should be performed.

\section{REFERENCES}

1. Pratik BM, Ashok GV, Pranita GA. A quest of anti-acne potential of herbal medicines for extermination of MDR Staphylococcus aureus. Int J Pharm Sci Invent. 2014; 3(6):12-7.

2. Nguyen R, Su J. Treatment of Acne vulgaris. Paediatrics and Child Health. 2011; 21(3):119-25.

3. Sinha P, Srivastava S, Mishra N, et al. New perspectives on antiacne plant drugs: contribution to modern therapeutics. BioMed Res Int. 2014:301-4.

4. Webster GF. Inflammation in Acne vulgaris. J Am Acad Dermatol. 1995; 33:247-53.

5. Bhalani U, Shah K. Preparation and evaluation of topical gel of Nigella sativa (kalonji). Int J Res Dev Pharm L Sci. 2015; 4(4):1669-72.

6. Aruna MS, Sravani A, Resshma V. Formulation and evaluation of herbal acne gel. World J Pharm Res. 2015; 4(5):2324-30.

7. Bowe WP, Logan AC. Acne vulgaris, probiotics and the gut-brainskin axis-back to the future? Gut Pathog. 2011; 3(1):1-11.

8. Kuver S, Palshikar G. Formulation and evaluation of herbal antiacne face wash. International Journal of Phytotherapy Research. 2014; 4(2):1-9.

9. Rai M, Yadav A, Gade A. Silver nanoparticles as a new generation of antimicrobials. Biotechnol Adv 2009; 27:76-83.

10. Tamizhamudu Elavazhagan, Kantha D Arunachalam. Memecylon edule leaf extract mediated green synthesis of silver and gold nanoparticles, Inter J Nanomed 2011; 6:1265-1278.

11. Reenu J, Shamina A, Chempakam B. In vitro antioxidant potential in sequential extracts of Curcuma caesia Roxb. Rhizomes. Indian J Pharm Sci 2015; 77(1):41-48.

12. Paliwal P, Pancholi SS, Patel RK. Pharmacognostic parameters for evaluation of the rhizomes of Curcuma caesia. J Adv Pharm Technol Res 2011; 2(1), 56-61.
13. Kokate CK, Purohit AP, Gokhale SB. Pharmacognosy, 47th Edn, Nirali Prakashan Publication, India. 2011.

14. Sumathy V, Jothy Lachumy S, Zuraini Z, et al. In vitro bioactivity and phytochemical screening of Musa acuminata flower. Pharmacologyonline. 2011; 2:118-27.

15. Zhishen J, Mengcheng T, Jianming $\mathrm{W}$. The determination of flavonoid contents in mulberry and their scavenging effects on superoxide radicals. Food Chem 1999; 64:555-9.

16. Shamsa F, Monsef H, Ghamooshi R, Verdian-rizi M. Spectrophotometric determination of total alkaloids in some Iranian medicinal plants. Thai J Pharm Sci 2008; 32:17-20.

17. Sharief N, Srinivasulu A, Uma Maheshwara Rao V. Estimation of alkaloids and total phenol in roots of Derris trifoliate and evaluation for antibacterial and antioxidant activity. Indian J Appl Res 2014; 4(5):1-3.

18. Narra K, Dhanalekshmi U, Rangaraj G, Raja D, Kumar C.S, Reddy P.N, Mandal A.B. Effect of formulation variables on rifampicin loaded alginate beads. Iranian J Pharm Res 2012; 11(3):715-721.

19. Nand P, Drabu S, Gupta RK, et al. In vitro and in vivo assessment of polyherbal topical gel formulation for the treatment of Acne vulgaris. Inter J Drug Del. 2012; 4:434-42.

20. Yamini K, Onesimus T. Preparation and evaluation of herbal anti-acne gel. Inter J Pharma Bio Sci 2013; 4(2):956-60.

21. Singh K, Panghal M, Kadyan S, et al. Evaluation of antimicrobial activity of synthesized silver nanoparticles using Phyllanthus amarus and Tinospora cordifolia medicinal plants. J Nanomed Nanotech 2014; 5(6):250.

22. Yamini K, Onesimus T. Preparation and evaluation of herbal anti-acne gel. Inter J Pharma Bio Sci 2013; 4(2):956-60.

23. Singh K, Panghal M, Kadyan S, et al. Evaluation of antimicrobial activity of synthesized silver nanoparticles using Phyllanthus amarus and Tinospora cordifolia medicinal plants. J Nanomed Nanotech. 2014; 5(6):250-255.

24. Sabri, H. S., Alia, W. K., Abdullahb, B. H., Al-Anic, W. M. Formulation design and evaluation of anti-microbial activity of emulgel containing essential oil of myrtus communis L. Inter J Pharm Sci Rev Res 40:271-277.

25. Balouiri M, Sadiki M, Ibnsouda SK. Methods for in vitro evaluating antimicrobial activity: A review. J Pharma Ana. 2016; 6:71-79.

26. Bhagat SA, Singh MC. Development and evaluation of silver nanoparticles and its applications in topical drug delivery systems. Asian J Pharm 2016; 10 (1):16-21.

27. Sreedam CD, Kaiser H, Jahan BI, Sultana S, Md, Islam S. In vitro antioxidant activity of different parts of the plant diospyros discolor. Res J Agric Biol Sci 2010; 6:472-5.

28. Kostyuk VA, Potapovich AI, Vladykovskaya EN, Korkina LG, Afanas'ev IB. Influence of metal ions on flavonoid protection against asbestos-induced cell injury. Arch Biochem Biophys 2001; 385(1):129-37. 